\title{
False Commitments: Local Misrepresentation and the International Norms Against Female Genital Mutilation and Early Marriage
}

\author{
Karisa Cloward
}

\begin{abstract}
A substantial international relations literature addresses the various ways in which international actors, and the norms they promote, influence state behavior. But less attention has been paid to the influence these actors directly exert at the local level, despite the fact that many transnational campaigns promote norms for which individuals - not states-are the primary transgressors. If individuals behave as some states do, publicly embracing international norms only because they expect a financial or reputational benefit from doing so, then the campaigns have not fully succeeded. But when do individuals engage in real behavior change, and when do they simply change the public image they present to the international community? To begin to address this question, I employ a randomized field experiment to evaluate individuals' willingness to make claims that differ from their true normative commitments. I conducted the experiment in the context of an original 2008 opinion survey about female genital mutilation and early marriage, run in rural Kenya. I find that respondents misrepresent their behavior and intentions, and I supplement these findings with an exploration of causal mechanisms through qualitative interviews.
\end{abstract}

A substantial International Relations (IR) literature addresses the various ways in which international actors, and the norms they promote, influence state behavior. ${ }^{1}$ But less attention has been paid to the influence these actors directly exert at the local level, despite the fact that many transnational campaigns promote norms for which individuals - not states — are the primary transgressors. What impact do international norms have on local actors? In some cases, communities are in the process of making genuine changes in their normative commitments in response to transnational activism. But particularly if one relies on individuals' self-reported attitude and

I am grateful to Frances Rosenbluth, Susan Hyde, Christopher Blattman, Elisabeth Wood, Donald Green, three anonymous reviewers, and the editors at International Organization for their helpful comments on earlier drafts of the article, and to Pierre Landry, Robert Person, Mario Chacon, and Ryan Sheely for their suggestions at various stages of the research and writing process. I am also indebted to the participants of the Yale University Jackson Institute/MacMillan Center International Relations Workshop at the Department of Political Science and of the Yale University Field Experiments Workshop for their feedback. I thank the Yale Institute for Social and Policy Studies and the Whitney and Betty MacMillan Center for International and Area Studies at Yale for research support.

1. Following Finnemore and Sikkink, I define a norm as a "shared standard of behavior appropriate for actors with a given identity." Finnemore and Sikkink 1998, 891. Individuals comply with norms in part because others expect them to and because there is a quality of "oughtness" to the behavior. 
behavior change to evaluate the effectiveness of transnational campaigns, there may be cause for skepticism about the true extent to which international norms have actually been embraced at the local level. If individuals behave as some states do, publicly embracing international norms only because they expect a financial or reputational benefit from doing so, then the campaigns have not fully succeeded. But when do individuals engage in real behavior change, and when do they simply change the public image they present to the international community?

To begin to address at least one aspect of this question, I employ a randomized field experiment to evaluate individuals' willingness to make claims that differ from their true normative commitments. ${ }^{2}$ I conducted the experiment in the context of an original 2008 opinion survey about female genital mutilation (FGM) and early marriage (two practices around which there is significant international-local norm conflict), run in Maa-speaking communities in rural Kenya. Kenya was an ideal setting for the experiment because it has significant subnational variation in the prevalence of FGM and early marriage, both across, and more importantly, within individual ethnic groups. The ability to focus on a single language family, and thus to "hold culture constant," makes it easier to isolate political factors that may contribute to individual and community responses to international norm promotion. ${ }^{3}$

In the experiment, half of the participants-the treatment group-were told that their answers would reach an international audience, while the other half-the control group - were told that their answers would reach a local audience. The experiment assesses whether the treatment group was more likely to declare opposition to the two practices. The survey analysis shows that there is indeed a divergence between the treatment and control groups in terms of respondents' self-reported past behavior and their intentions with respect to future behavior. Being informed of an international audience to the survey decreases by at least eleven percentage points the probability of reporting plans to circumcise a daughter in the future, and decreases by an even larger margin the probability of admitting to having a daughter who was married before she turned eighteen. These findings are supported by evidence from qualitative interviews conducted with community stakeholders. The qualitative data help to elucidate the causal mechanisms motivating individuals to conceal their true feelings about FGM and early marriage, showing that efforts at misrepresentation are the product of a desire to obtain both psychological and material

2. Misrepresentation is, of course, just one aspect of the interaction between international norms and subnational actors. While in this article I treat individuals' true attitudes and behavior as given, I explore other elements of norm change, including attitude and behavior change, in an ongoing project. See Cloward forthcoming.

3. The focus on Kenya is not meant to imply that Africans in general or Kenyans in particular are uniquely prone to making false commitments to international norms. Studies conducted in the United States have found evidence of a "social desirability" bias in survey response, on topics ranging from voting behavior and charitable giving to racial prejudice. See Parry and Crossley 1950; and Phillips and Clancy 1972. A number of cross-national studies have also identified social desirability effects in a wide range of cultural contexts. See, for example, Türk Smith, Smith, and Seymour 1993; and Williams, Satterwhite, and Saiz 1998. 
benefits from international actors. The qualitative interviews further suggest that community members may also seek material benefits from local community activists, though the vast majority of the local organizations advocating against FGM and early marriage are themselves funded primarily by international actors.

Why does it matter if people hide their behavior? It is important to consider the full range of possible responses to transnational activism, even if some of those responses are unintended. In order to evaluate whether international norms are having an effect, one needs to know whether claims of normative change are in fact true. By investigating not just whether misrepresentation occurs, but also the motivations for that misrepresentation, one begins to construct a more complete picture of the processes by which local-level norm change might be achieved.

\section{Transnational Activism, Norms, and Misrepresentation}

Many IR scholars have investigated the role and importance of international norms, and particularly the promotion of international norms by groups of activists through a process of transnational advocacy. ${ }^{4}$ But both the broader norms literature and the transnational advocacy literature have tended to focus on the way norms influence states' behavior. An implicit assumption underlying prominent theories such as Keck and Sikkink's "boomerang" model is that activists are proxies for the domestic population-the general public and the international community agree on what is "right" or progressive, and the relevant target for activism is the retrogressive state. ${ }^{5}$ Certainly this configuration of interests accurately describes a range of transnational campaigns, including those related to state-sanctioned "disappearances," universal suffrage, anti-Apartheid, clean energy policy, and freedom of the press. However, there are also issues for which the major barrier to normative change is not the state, but rather the people who live within it. Individuals are the ones who, for example, poach endangered species, cut and burn trees for charcoal, and refuse to wear condoms to prevent HIV transmission or to vaccinate their children against a range of preventable diseases. If individuals are responsible for these behaviors, then, particularly where the state has limited enforcement capacity, individuals are the appropriate targets for norm promotion.

In recognition that the state cannot always impose international norm compliance from above, a few studies have considered the role nonstate actors might play in the process of norm change. Lutz and Sikkink, for example, argue that when decision making about a given action is decentralized-in particular they point to the fact that local political actors can make decisions about the use of torture without the direct consent of the central state-efforts to achieve international norm compliance

4. See Finnemore 1993; Finnemore and Sikkink 1998; Keck and Sikkink 1998; Klotz 1995; Nadelmann 1990; Price 1998; and Risse and Sikkink 1999.

5. Keck and Sikkink 1998, 12. 
can slow or stall. ${ }^{6}$ However, as Simmons points out in her review of the international law literature, the topic of nonstate actors as major players in determining norm compliance remains understudied. ${ }^{7}$

This problem persists when the focus narrows to activism on the issue of violence against women, a category that includes efforts to eradicate FGM and early marriages. ${ }^{8}$ Even where the literature has considered the role of the general public in inhibiting norm change, the actions of the state and of activists themselves nonetheless dominate the discourse. For example, in her study of gender violence in Russia, Johnson considers whether foreign intervention promotes broader public awareness of violence against women, but when it comes to actual substantive change her focus is primarily on state policies. ${ }^{9}$ Sundstrom, also looking at the Russian case, recognizes that a hostile public may be more of a barrier to change than the state itself, and briefly considers whether the women's movement has influenced some nonstate behavior-specifically, women reporting cases of domestic violence to authorities-yet this is secondary to the effects of activism on state conduct. ${ }^{10}$ Merry investigates how local activists appropriate and adapt the language of the international human rights regime on gender violence, but she concentrates on when and how women use these reinterpreted international norms to place claims on the state, not on the men in their communities. ${ }^{11}$

Thus there is a critical gap in the literature, and a clear need to evaluate the ways in which individuals and communities respond to transnational activism and norm promotion when it comes to issues such as violence against women. This is particularly important because bringing about local-level conformity with international norms can be a fraught process. As Finnemore and Sikkink note, "New norms never enter a normative vacuum." 12 Although transnational activists may promote international norms against FGM and early marriage, many communities subscribe to strong local norms supporting the two practices. For local behavior change to occur, individuals must be convinced to reject the existing local norms and embrace the international ones. Yet to the extent that people believe the international norms to be fundamentally at odds with the local norms, it is unlikely that a campaign will produce rapid behavior change at the local level. ${ }^{13}$ Nonetheless, transnational activism may still have an effect on individuals' actions, even if that effect is unanticipated or unintended.

6. Lutz and Sikkink 2000, 639.

7. Simmons 2010, 292.

8. According to the UN Declaration on the Elimination of Violence against Women, violence against women is "any act of gender-based violence that results in, or is likely to result in, physical, sexual or psychological harm or suffering to women."

9. Johnson 2009, 11-13.

10. Sundstrom 2005, 422, 442.

11. Merry 2006, 215-16.

12. Finnemore and Sikkink 1998, 897.

13. Examples of rapid norm shifts are not unheard of, however. Mackie describes the swift eradication of footbinding in China in response to a concerted campaign. Mackie 1996, 1001. 
The existing international norms literature, despite its state-centrism, can shed some light on what these unintended consequences might look like in practice. Indeed, IR theory offers several avenues by which to interpret states' decisions to publicly sign on to international norms. Constructivists highlight moral suasionthe triumph of ideas through a normative discourse, and often, direct activism. ${ }^{14}$ Rational actor models, on the other hand, emphasize either the epiphenomenal or instrumental nature of these accessions - the norm itself is a product of states' existing interests, or else states derive benefits from compliance that outweigh any costs. However, both approaches recognize, either implicitly or explicitly, that rhetorical allegiance to international norms is not equivalent to compliance with international norms. It is possible for states to make public commitments to international norms without actually following through on those commitments. ${ }^{15}$ The promise of foreign aid, international trade and investment, and membership benefits in international organizations; fear of punishment or sanction; and reputational and status concerns can encourage states to attempt to signal compliance with international norms-especially if those signals are relatively costless-despite contradictory behavior.

For example, Hathaway and Vreeland each point to authoritarian states that have willingly signed human rights treaties such as the Convention Against Torture (CAT), a step that serves as a public signal of commitment to norms promoting human rights. ${ }^{16}$ However, because treaties such as the CAT are essentially unenforceable, states risk little by disingenuously signing them, and they may gain various international benefits. Along similar lines, Subotić considers how international pressure can encourage postconflict states to technically adopt transitional justice mechanisms while failing to embrace the deeper meaning of the international norm supporting these mechanisms. ${ }^{17}$ Indeed, even when the signal is fairly costly-as in the case of election observation-states may still find it in their interest to attempt to mask their true type to the international community. ${ }^{18}$

This disjuncture between states' rhetoric and behavior has a natural corollary in the actions of individuals. Indeed, much of the theoretical underpinning of arguments about states' desire for legitimacy is derived from psychological literature on individuals' reactions to peer pressure and other aspects of group dynamics. ${ }^{19}$ These findings have often been aggregated up to the state level, with corresponding assumptions about states as unitary actors. Refocusing on the individual level allows one to dispense with such assumptions.

Research in psychology provides a basis for understanding how both reputational and material motivations might lead to the projection of an international-norm-compliant

14. See Finnemore and Sikkink 1998, 895; and Keck and Sikkink 1998, 4-5.

15. See Hathaway 2002, 1940; and Hafner-Burton and Tsutsui 2005, 1374.

16. See Hathaway 2003, 1838-39, and 2007, 590; and Vreeland 2008, 70.

17. Subotić 2009, 36-37.

18. Hyde 2011, 3.

19. Finnemore and Sikkink 1998, 903-4. 
image. A relevant strain of the social psychology literature on attitudes focuses on a concept called self-presentation, sometimes referred to as image management. ${ }^{20}$ Selfpresentation concerns "the seminal idea that people attempt to regulate and control, sometimes consciously and sometimes without awareness, information they present to audiences, particularly information about themselves." ${ }^{21}$ Although image management may be motivated by a range of goals, one important motivation is that "conveying the right impression increases the likelihood that one will obtain desired outcomes and avoid undesired outcomes. Some such outcomes are interpersonal in nature, such as approval, friendship, assistance, power, and so on ... [whereas] other such outcomes are material." 22

Different audiences, and the norms and expectations they endorse, can elicit different versions of the self and "alter the norms and roles that seem relevant." 23 Individuals are more likely to present a version of the self that is in line with the preferences of the audience when that audience is significant in some way, whether because of power, high status, expertise, or some other valued characteristic. ${ }^{24}$ Ingratiating oneself to an audience, through, for example, "opinion agreement," is particularly desirable when the actor is somehow dependent on the audience. ${ }^{25}$ These kinds of dynamics are certainly present in the unequal relationship between subnational and international actors. International actors can carry significant prestige and authority, and they also have control over the aid distribution from which many rural communities benefit. It is thus no surprise that some individuals will seek to be perceived favorably by international actors, and that one way to accomplish this is to appear compliant with these actors' favored norms.

Self-presentation can involve an essentially honest, if selective, portrayal of oneself, but it can also involve deception when reality does not mirror the image one wishes to project. ${ }^{26}$ DePaulo and colleagues find that outright lying in regular social interactions is quite common, generally self-serving (as opposed to benefiting others), and, importantly, most often motivated by a desire for psychological, rather than material, benefits. ${ }^{27}$ Individuals in their study lied to "make themselves appear kinder or smarter or more honest than they believe themselves to be and to protect themselves from embarrassment or disapproval or conflict." 28 Essentially, people lied to be perceived as more agreeable by the person to whom they were telling the lie. This may be easier to achieve when the relationship between presenter and audience is fairly superficial, as is the case with rural residents and international

20. Goffman 1973, 259.

21. Schlenker and Weigold 1992, 134.

22. Leary and Kowalski 1990, 37.

23. Schlenker and Weigold 1992, 154.

24. Nowak, Szamrej, and Latané 1990, 365.

25. Jones 1990, 178-79.

26. See Schlenker and Weigold 1989, 253; and Tetlock and Manstead 1985, 62.

27. DePaulo et al. 1996, 991.

28. Ibid., 991. 
actors. ${ }^{29}$ That is, there is a high probability that international actors will believe those who present themselves as opponents of FGM or early marriage, because these actors are unlikely to have recurring interactions with the same individual, and are similarly unlikely to be able to investigate any one individual's claims.

Although the psychology literature points to reputational motives dominating material motives for misrepresentation, there may still be financial incentives to dissimulate. ${ }^{30}$ Rural communities are unlikely to be the direct recipients of large-scale foreign aid in the same way that states are, but they may still benefit indirectly, considering that donor funds have been increasingly funneled through international nongovernmental organizations (NGOs) to local groups, particularly since the 1990s. Because of this funding pathway, donors' interests tend to become the stated interests of NGOs on the ground. ${ }^{31}$ As Hulme and Edwards note, "Supplying increasing volumes of funds to [southern NGOs] is encouraging them to pursue activities and take on structural forms that enhance the likelihood of access to funds." 32 Moreover, Ottaway and Carothers emphasize that the availability of donor funding has not merely caused existing organizations to alter their behavior-it has also led to the creation of many thousands of brand new organizations with missions that hew closely to donor priorities. ${ }^{33}$ Sundstrom rightly points out that local NGOs' new stated priorities may or may not be genuine-local activists may also present different images to donors and international audiences than to their local communities, particularly if those communities are hostile to the international norms in question - but even a disingenuous adoption of donor priorities can have an impact. ${ }^{34}$ Through the sheer volume of talk by donors and their local proxies, individuals even in rural areas are likely to discover what the international community wants to hear, and some may ultimately conclude that expressing agreement with donor preferences is a good way to access donor support.

Regardless of motivation, deceptive self-presentations allow one to create a desired identity that is not mirrored by reality. This desired identity may reflect pure strategy, but it can also be aspirational-the identity is one that the presenter wishes were true. ${ }^{35}$ Either of these motivations is possible in the context of competing norms. That is, one may for strategic reasons want to be perceived by an international audience as complying with the international norm, while simultaneously holding

\section{Buss and Briggs 1984, 1313.}

30. However, it is worth noting that the effects of material incentives may not be unidirectional. Goodman and Jinks argue that material incentives have the potential to reduce international norm commitments, through a variety of psychological mechanisms. In variations of what they call the "overjustification" effect, individuals may avoid commitments to international norms when material incentives are in place precisely because they do not want to be perceived as being motivated by financial considerations (a "social signaling" effect), or because they do not want to see themselves or be perceived by others as susceptible to external pressures (a "self-determination" effect). Goodman and Jinks 2013, 108, 112.

31. See Edwards and Hulme 1995, 5; and Smillie 1995, 158.

32. Hulme and Edwards 1997, 9.

33. Ottaway and Carothers 2000, 299.

34. Sundstrom 2006, 104.

35. Schlenker and Weigold 1992, 139-40. 
contradictory opinions. However, it is also possible for an individual to wish to comply with the international norm, and present him- or herself accordingly to international actors, but feel too bound by the local norm to actually fulfill that wish in reality.

The social psychology literature dovetails nicely with both constructivist and rational actor models of international norm accession in IR theory, presenting a conception of decision making that does not force one to choose between moral and instrumental motivations. It treats individuals as complex actors, and this approach is useful as one considers the range of responses to norm promotion in an international relations context.

The takeaway point is that an incentive for misrepresentation exists whenever individuals' loyalties and commitments are being pulled in diametrically opposite directions. When faced with norm conflicts such as those surrounding FGM and early marriage, one can try to please everyone, but cannot do so honestly. Individuals must ultimately choose whether to present themselves accurately to all audiences and risk alienating one side or the other, or to try to have the best of both worlds through misrepresentation.

\section{FGM and Early Marriage: Campaign and Practice}

The broader transnational campaign on violence against women has created and now promotes international norms against the practices of FGM and early marriage. On the other hand, communities that practice female circumcision and early marriage are subscribing to local norms supporting these customs.

FGM and early marriage are both recognized internationally as harmful traditional practices. ${ }^{36}$ An estimated 125 million women and girls alive today have undergone FGM, with as many as three million African girls at risk annually. ${ }^{37} \mathrm{FGM}$ is practiced in twenty-nine countries in Sub-Saharan Africa and the Middle East, as well as among isolated groups in Southeast Asia and among some immigrant communities in North America and Western Europe. Early marriages occur in all regions of the world, though prevalence varies significantly. According to the United Nations Children's Fund (UNICEF), more than one in three women between the ages of twenty and twenty-four in the developing world were married by the time they

36. I use the term female genital mutilation (as opposed to female genital cutting) when referring to the international and domestic campaign against the practice, because it remains the most widely used term among activists. However, I use the term female circumcision when speaking about individuals and communities who engage in the practice. Though the word circumcision does not adequately illustrate the procedure's severity - equating it with the far less invasive practice of male circumcision - this is the way that Maa-speaking communities genuinely perceive the practice. I use the term early marriage (as opposed to child marriage or forced marriage) because it is relatively value-neutral and is an accurate depiction of the nature of the practice. However, the appropriate terminology continues to be debated by activists and academics alike.

37. United Nations Children's Fund 2013, 114. 
turned eighteen, including 46 percent in South Asia and 39 percent in Sub-Saharan Africa. $^{38}$

The World Health Organization (WHO) provides a widely accepted definition of FGM as a practice comprising "all procedures that involve partial or total removal of the external female genitalia, or other injury to the female genital organs for non-medical reasons." 39 The three main types of FGM are clitoridectomy, which involves the removal of part or all of the clitoris; excision, which involves the removal of the clitoris and part or all of the labia minora; and infibulation, which involves the removal of the clitoris, labia minora, and labia majora, as well as the subsequent stitching or narrowing of the vaginal opening. Most girls undergo FGM sometime between infancy and age fifteen, although occasionally the practice is carried out on adult women.

Early marriage is defined simply as marriage of children and adolescents under the age of eighteen. Although boys are occasionally subjected to this practice, the overwhelming majority of early marriages involve girls married to older men. There is often a significant age difference between the husband and wife, and many early marriages are also polygynous. ${ }^{40} \mathrm{~A}$ girl may be actually forced into marriage or she may simply be too young to make an informed decision about marriage and thereby give consent. ${ }^{41}$

The formation of the international norms against FGM and early marriage is based on a logic of health, gender equality, and human rights. According to the WHO, FGM "is recognized internationally as a violation of the human rights of girls and women. It reflects deep-rooted inequality between the sexes, and constitutes an extreme form of discrimination against women. It is nearly always carried out on minors and is a violation of the rights of children. The practice also violates a person's rights to health, security, and physical integrity; the right to be free from torture and cruel, inhuman, or degrading treatment; and the right to life when the procedure results in death." 42 Early marriage violates many of these same rights, as well as the right to consensual marriage. ${ }^{43}$

The international norms against FGM and early marriage are codified in international treaties and other consensus documents. The Protocol to the African Charter on Human and People's Rights on the Rights of Women in Africa and the Beijing Declaration and Platform for Action of the Fourth World Conference on Women explicitly address FGM and early marriage, and the Convention on the Elimination of All Forms of Discrimination Against Women and the African Charter on the Rights and Welfare of the Child also directly prohibit early marriages.

38. UNICEF 2009, 10.

39. WHO 2008.

40. Polygyny is a form of marriage in which one man has two or more wives.

41. UNICEF Innocenti Research Center 2001, 2.

42. WHO 2008.

43. See International Planned Parenthood Federation 2006, 22-25; and UNICEF Innocenti Research Center 2001, 3. 
The modern transnational campaign against FGM gained momentum in the 1970s. Since then, networks of international and local activists have worked to reframe "female circumcision" as "female genital mutilation," mobilized the United Nations and other international organizations, and delivered their message to a wide range of communities throughout Africa. But despite the intensive campaign, the international norm still faces substantial resistance from communities that practice female circumcision. This is because the local norm is based on a logic of its own. Many justifications have been advanced in defense of female circumcision, though the particular mix of such justifications varies across countries, ethnic groups, and individual communities. In different contexts female circumcision can serve as a rite of passage to adulthood, as a method for ensuring premarital virginity and marital chastity, as a means of promoting femininity, modesty, and "cleanliness," and/or as a religious requirement. ${ }^{44}$

Activism against early marriage has not been associated with a dedicated international campaign, but there is nonetheless a clear international norm against the practice, and a fair amount of activism associated with broader efforts to promote women's rights. The logic of the local norm supporting early marriage is based partly in economic need, as well as culture and religion. In impoverished areas, girls are often perceived as an economic burden, while their marriage may bring a bridewealth of money, livestock, or other goods. Stigma associated with premarital sex and pregnancy out of wedlock may also motivate parents to marry off their daughters at a young age. ${ }^{45}$

Among countries for which reliable data are available, Kenya has an FGM prevalence rate that falls slightly below the median of the distribution. ${ }^{46}$ The 2008-2009 Kenya Demographic and Health Survey (DHS) found that 27 percent of women had undergone the procedure, a five-percentage-point decline from the 2003 round of the survey and an eleven-percentage-point decline from 1998. ${ }^{47}$ By ethnic group, the highest reported prevalence rates were among the Somali (98 percent), Kisii (96 percent), and Maasai (73 percent). Overall, prevalence rates declined sharply with age - 49 percent of women aged forty-five to forty-nine reported having been cut, compared with only 15 percent of women aged fifteen to nineteen. This decline in FGM prevalence among younger age cohorts suggests that overall prevalence rates may continue to fall in the future.

As with FGM, early marriage prevalence in Kenya also appears to have been declining. The 2008-2009 DHS found that among all women aged twenty to fortynine, 8 percent had been married by age fifteen and 31 percent had been married

44. WHO 2008.

45. International Planned Parenthood Federation 2006, 18-20.

46. UNICEF Innocenti Research Center 2005, 4.

47. See Kenya National Bureau of Statistics and ICF Macro 2010, 265; Kenya Central Bureau of Statistics, Ministry of Health, and ORC Macro 2004, 251; and Kenya National Council for Population and Development, Central Bureau of Statistics, and Macro International 1999, 168. 
by age eighteen. ${ }^{48}$ By ethnic group, the highest rates of early marriage were among the Somali (22 percent married by age fifteen and 50 percent by age eighteen), Mijikenda (18 percent married by age fifteen and 48 percent by age eighteen), and Maasai (17 percent married by age fifteen and 46 percent by age eighteen). Although fully 40 percent of all women aged forty-five to forty-nine had been married by age eighteen, only 26 percent of women aged twenty to twenty-four had been married by that age. The decline in early marriage across age cohorts is mirrored by a decline over time, although that decline appears to have leveled off. The 2008-2009 early marriage prevalence rates are the same as the 2003 rates, but they are three percentage points lower than the 1998 rate for marriage by age fifteen and four percentage points lower than the 1998 rate for marriage by age eighteen. ${ }^{49}$

The reported declines in FGM and early marriage prevalence have tracked legal and policy changes by the government of Kenya. In 2001 Kenya passed the Children's Act, which outlawed early marriage and FGM before the age of eighteen. Various government ministries have also coordinated on a National Plan of Action for the Elimination of Female Genital Mutilation in Kenya, and as early as 1982, President Daniel arap Moi publicly condemned FGM, partly in response to the deaths of fourteen girls from medical complications stemming from the operation. ${ }^{50}$ Still, the limited enforcement of the Children's Act should make one skeptical that legal and policy changes are primarily responsible for the reduced prevalence of the two practices. Arrests under the act have been rare, and actual prosecutions even less common, since the police receive few reports about the practices and generally have minimal motivation or resources to pursue reports they do receive. The Kenyan court system is also heavily backlogged, so cases involving "traditional practices" tend to receive low priority and are unlikely to go to trial.

But particularly because this article is concerned with misrepresentation, it is important to consider the possibility that the reported declines in FGM and early marriage over time are just a consequence of increased reporting bias following the introduction of the Children's Act-women who participated in the 2003 and 2008-2009 rounds of the DHS might simply be disinclined to admit that they underwent an illegal practice. However, comparison of the 1998, 2003, and 2008-2009 surveys suggests that such misrepresentation cannot account for the overall decline. For example, if one restricts the survey data to only those age cohorts who were present in all three rounds-women aged fifteen to thirty-nine in 1998, aged twenty to forty-four in 2003, and aged twenty-five to forty-nine in 2008-the decline in FGM prevalence becomes much smaller. Within these age groups, 36 percent of respondents in 1998 reported having been cut, compared with 35 percent in 2003 and 34 percent in 2008-2009. Thus, some new misrepresentation

48. Kenya National Bureau of Statistics and ICF Macro 2010, 83.

49. Kenya Central Bureau of Statistics, Ministry of Health, and ORC Macro 2004, 93; Kenya National Council for Population and Development, Central Bureau of Statistics, and Macro International 1999, 70. 50. "Circumcision of Females is Banned in Kenya," Globe and Mail (Canada), 22 September 1982. 
may have occurred, but not at nearly a high enough rate to account for the eleven-percentage-point drop in reported prevalence for the full sample between 1998 and 2008-2009. Instead, the larger decline is primarily accounted for by the entry of younger women into and the exit of older women out of successive rounds of the survey.

Within Kenya, the Maa language family includes a number of related pastoralist groups, of which the Maasai and Samburu are the largest, jointly making up between 2 and 3 percent of the Kenyan population. ${ }^{51}$ Maasai and Samburu share very similar cultural practices, including a long tradition of female circumcision and early marriage. The Maasai population is concentrated in the southern Rift Valley and straddles the Kenya-Tanzania border, while the Samburu are concentrated in the northern Rift Valley to the south and east of Lake Turkana.

Maasai and Samburu girls are traditionally circumcised around the time at which they first begin menstruating. Circumcision serves as a rite of passage into adulthood, although unlike with Maasai and Samburu boys, the ritual does not serve as a test of bravery - girls are allowed to cry out or otherwise show their pain. Traditionally, girls are then married within a few days to a few months after their circumcisions. The bridegroom's family pays a bridewealth to the bride's family in exchange for taking the girl away to live at her new husband's homestead. A girl's parents generally make the arrangements for both circumcision and marriage-girls themselves tend to have little control over either proceeding.

The fact that female circumcision and early marriage are long-standing traditions among Maasai and Samburu creates a significant challenge for promoters of the international norms against these practices. However, not all Maa-speaking peoples have responded in the same way. The three rural case study areas-Oldonyiro, Mukogodo, and Mau-represent significant variation in their openness to norm change. Figure 1 maps the three communities. ${ }^{52}$

Oldonyiro, which is predominantly Samburu, is the least accessible community in terms of travel time from the capital and road conditions, and has no real urban centers. Its residents also have the fewest opportunities to receive an education. Mukogodo falls in the middle, with some significant challenges in terms of accessibility but also a fairly substantial network of schools and an ethnically heterogeneous urban center. Its population is primarily Maasai. ${ }^{53} \mathrm{Mau}$, which is also mainly Maasai, is the most cosmopolitan and networked of the three, with a substantial urban population, easy accessibility from major hubs, and plenty of schools.

51. See Sommer and Vossen 1993, 32; and Kenya Central Bureau of Statistics 1989.

52. At the time I conducted the research, Kenyan administrative levels were organized in descending order of province, district, division, location, and sublocation. Oldonyiro, Mukogodo, and Mau are each administrative divisions, but because Mau division is much larger than the other two, I focus on only two of its locations-Keekonyokie and Suswa. However, I refer to these two locations collectively as Mau for ease of reference.

53. More specifically, the area is dominated by five Maa-speaking subtribes that came to identify as Maasai during the colonial period. Cronk 2004, 61-62. 


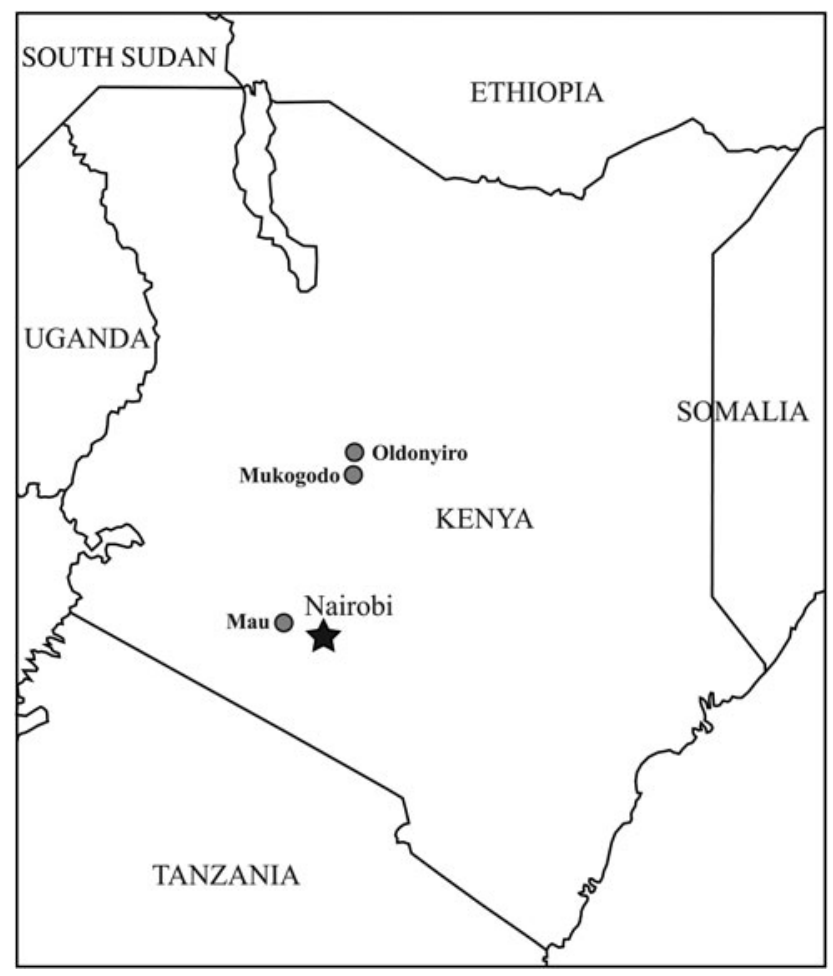

FIGURE 1. Case study areas

These differences have been important for explaining existing levels of international norm awareness and behavior change. Because of its inaccessibility and low educational provision, Oldonyiro has been the recipient of very little activism against FGM and early marriage-few international- or national-level NGOs have been willing to make the trek out to the area, few local NGOs have been created, and few children have attended schools in which they might have heard messages against FGM or early marriage. Because of low international norm awareness, the people of Oldonyiro have little incentive to hide their local-norm-compliant behavior from an international audience. In Mukogodo, by contrast, a fair number of local NGOs have sprung up in the past decade and some international- and nationallevel NGOs have visited as well, leading to reasonably high awareness of the international norms against FGM and early marriage. Still, real behavior change has not yet become widespread, and the disconnect between awareness and behavior provides fertile ground for misrepresentation to an international audience. Of the three case study areas, Mau has made the greatest progress in embracing the international norms against FGM and early marriage, in part because of a long-term and consistent campaign by local, national, and international NGOs; proximity to Nairobi; and 
frequent interaction with the high-status but generally noncircumcising Kikuyu community. Still, the decline in FGM and early marriage prevalence is far from complete, so incentives to misrepresent one's normative commitments to international actors persist.

\section{Experimental Evidence}

\section{Survey Design}

To assess individuals' willingness to commit to the international norms against FGM and early marriage while simultaneously maintaining their compliance with local norms, a randomized experiment was embedded in a representative survey, conducted in November 2008, of Maasai and Samburu in the three case study areas. Each study area had a sample size of 200 , for a total sample size of 600 , selected through a random walk procedure. ${ }^{54}$

Respondents-male and female Maa-speakers aged fifteen to eighty-five-were asked a series of questions designed to assess their knowledge, attitudes, and behavior with respect to both FGM and early marriage. ${ }^{55}$ Each questionnaire was conducted verbally and entirely in the Maa language, and care was taken to ensure that question wording was as value-neutral as possible. For example, the survey always referred to FGM as emuratare oo ntoyie (literally, "circumcision of girls"), which is the local term for the practice, and to early marriage as kiama egorr ilarin tomon osiet ("marriage before age eighteen") or enkima oo ntoyie ("marriage of girls"). Although all respondents were asked the same set of questions, half of the respondents were randomly assigned to receive priming statements emphasizing an international audience interested in the outcome of the survey. ${ }^{56}$

The first priming statement appeared at the beginning of the survey:

This questionnaire was developed in consultation with American researchers from Yale University. These researchers will look at the responses you give

54. The survey used a multistage sampling design, in which the primary sampling unit was the case study area, the secondary sampling unit was the sublocation, the tertiary sampling unit was the household, and the final sampling unit was the individual. The Steadman Group, a survey research firm headquartered in Nairobi, was contracted to oversee the field administration of the survey. A field supervisor accompanied the enumerators on 6.3 percent of all interviews, and back-checked 11.2 percent of all interviews with the respondents.

55. The survey questionnaire was largely original, although it included select questions from Afrobarometer and the Measure DHS Demographic and Health Surveys.

56. 292 of the 600 respondents were assigned to the treatment group, and 308 were assigned to the control group. By randomly assigning respondents to the treatment and control groups, the survey experiment avoided the common problem of selection bias. Under normal circumstances, rural individuals who are exposed to international actors no doubt differ systematically from individuals who are not exposedthey likely live in relatively more urban areas, are better educated, have traveled more, and are generally more cosmopolitan. Especially because some of these variables are difficult to measure with precision, it is helpful to be able to take such selection effects out of the equation. 
and share them with organizations and policymakers in other countries, like the United States and England, and with international organizations like the United Nations. The results will also be shared with international newspapers, like the New York Times, that are read by millions of people around the world.

A second statement appeared directly before a series of personal opinion questions, to remind respondents that their opinions were of particular interest to an international audience:

Now I would like to ask about your opinions on circumcision and marriage. The American researchers who have developed this survey are especially interested in the answers you provide to these next questions, as are the international organizations and foreign policymakers with whom the Americans are working. Because circumcision and early marriages are issues that the Americans and the United Nations care about very deeply, they will be looking at your answers to help them make decisions about future programs and policies.

A local partner NGO or community-based organization (CBO) in each division served as the public face of the survey, to avoid contaminating the experiment by making myself (an international observer) a visible part of the process for both the treatment and control groups. ${ }^{57}$ The three groups were Pastoralist Women for Health and Education in Oldonyiro, the Indigenous Laikipiak Maasai Integrated Youth Organization (ILAMAIYO) in Mukogodo, and Tasaru Ntomonok Initiative in Mau. ${ }^{58}$ Additionally, questionnaire enumerators were recruited from within each study area.

The control group received a version of the questionnaire that included priming statements about the presence of a local audience, in order to ensure that any recorded treatment effect was not simply a response to the signal about the presence of an audience generally, as opposed to an international audience specifically. The two control group priming statements were worded similarly to the treatment group, and read as follows:

This questionnaire was developed in consultation with some other people from this area. [ILAMAIYO/Pastoralist Women for Health and Education/Tasaru Ntomonok Initiative] will look at the responses you give and share them with the community. The results will also be shared with newspapers that are read by people in this area.

57. In Kenya, the distinction between an NGO and a CBO is a legal one. While CBOs are meant to be tied to a specific geographic area, NGOs have more freedom to expand their operations to new areas of the country. The distinction does not relate to the size of the organization-some CBOs are larger than some NGOs_-or to the organization's funding sources-many registered CBOs are directly funded by international organizations. Also, in practice, many registered NGOs operate in circumscribed geographic areas no larger than CBOs' areas of operation.

58. While the three groups may well have slightly different reputations in their respective communities, the potential effect this might have on response should be the same for both the treatment and control groups, and thus should not interfere with the experimental design. 
Now I would like to ask about your opinions on circumcision and marriage. [ILAMAIYO/Pastoralist Women for Health and Education/Tasaru Ntomonok Initiative] is especially interested in the answers you provide to these next questions, as are other organizations from this area. Because circumcision and early marriages are issues that [ILAMAIYO/Pastoralist Women for Health and Education/Tasaru Ntomonok Initiative] and these other local organizations care about very deeply, they will be looking at your answers to help them make decisions about future programs and policies.

If respondents in the treatment group respond systematically differently to questions about their attitudes and behavior than respondents in the control group, this will be supporting evidence that at least some individuals faced with a norm conflict are willing to hide their true preferences and actions in the hope of gaining some type of benefit from the international community.

\section{Measuring Attitudes, Experiences, and Behavior}

The survey included a number of indicators of attitudes, experiences, and behavior associated with FGM and early marriage. Table 1 presents descriptive statistics. In expressing their attitudes, 40 percent of respondents reported that they thought FEMALE CIRCUMCISION SHOULD BE STOPPED, whereas 46 percent thought it should continue and 14 percent said their attitude depended on other circumstances. 26 percent of respondents reported that there were NO BENEFITS ASSOCIATED WITH FEMALE CIRCUMCISION, whereas 53 percent reported that they would PREFER THEIR SON MARRY A CIRCUMCISED WOMAN. With respect to early marriage, 62 percent reported that they thought EARLY MARRIAGE SHOULD BE STOPPED, whereas 29 percent thought it should continue and 9 percent said their attitude depended on other circumstances. Additionally, 62 percent reported that there were NO BENEFITS ASSOCIATED WITH EARLY MARRIAGE.

Respondents were also asked about their own experiences, with 89 percent of female respondents reporting that they themselves were CIRCUMCISED, and 43 percent reporting that they had MARRIED BEFORE AGE EIGHTEEN, for a mean female marriage age of 18.5. Finally, respondents were asked about their past behavior and intended future behavior with respect to their daughters, since parents are generally the decision makers when it comes to FGM and early marriage. Among respondents with daughters, 54 percent stated that at least one DAUGHTER HAD BEEN CIRCUMCISED, while among respondents with ever-married daughters, 55 percent reported that the most recently married DAUGHTER HAD BEEN MARRIED BEFORE AGE EIGHTEEN, for a mean marriage age of 17.7.59 In terms of future behavior, 60 percent of respondents with uncircumcised daughters stated that they intended to CIRCUMCISE THEIR DAUGHTERS IN THE FUTURE.

59. The percentage reporting that at least one daughter had been circumcised is low because the question was asked of all respondents with daughters, even if those daughters were too young to be circumcised at the time. 
TABLE 1. Descriptive statistics

\begin{tabular}{|c|c|c|c|c|c|}
\hline & \multirow{2}{*}{$\frac{\text { Oldonyiro }}{\text { Mean }}$} & \multirow{2}{*}{$\frac{\text { Mukogodo }}{\text { Mean }}$} & \multirow{2}{*}{$\frac{M a u}{\text { Mean }}$} & \multicolumn{2}{|c|}{ All areas } \\
\hline & & & & Mean & Observations \\
\hline \multicolumn{6}{|l|}{ Attitudes } \\
\hline FEMALE CIRCUMCISION SHOULD STOP & $\begin{array}{c}0.097 \\
(0.02)\end{array}$ & $\begin{array}{c}0.428 \\
(0.04)\end{array}$ & $\begin{array}{c}0.571 \\
(0.04)\end{array}$ & $\begin{array}{c}0.402 \\
(0.02)\end{array}$ & 592 \\
\hline FEMALE CIRCUMCISION VIEW CHANGED & $\begin{array}{c}0.089 \\
(0.02)\end{array}$ & $\begin{array}{r}0.417 \\
(0.04)\end{array}$ & $\begin{array}{c}0.336 \\
(0.04)\end{array}$ & $\begin{array}{c}0.298 \\
(0.02)\end{array}$ & 588 \\
\hline FEMALE CIRCUMCISION HAS NO BENEFITS & $\begin{array}{c}0.103 \\
(0.02)\end{array}$ & $\begin{array}{c}0.162 \\
(0.03)\end{array}$ & $\begin{array}{c}0.432 \\
(0.04)\end{array}$ & $\begin{array}{c}0.258 \\
(0.02)\end{array}$ & 596 \\
\hline PREFER SON MARRY CIRCUMCISED WOMAN & $\begin{array}{c}0.821 \\
(0.03)\end{array}$ & $\begin{array}{c}0.549 \\
(0.04)\end{array}$ & $\begin{array}{r}0.333 \\
(0.04)\end{array}$ & $\begin{array}{c}0.529 \\
(0.02)\end{array}$ & 597 \\
\hline EARLY MARRIAGE SHOULD STOP & $\begin{array}{c}0.147 \\
(0.03)\end{array}$ & $\begin{array}{c}0.621 \\
(0.04)\end{array}$ & $\begin{array}{c}0.900 \\
(0.02)\end{array}$ & $\begin{array}{c}0.616 \\
(0.02)\end{array}$ & 592 \\
\hline EARLY MARRIAGE VIEW CHANGED & $\begin{array}{r}0.087 \\
(0.02)\end{array}$ & $\begin{array}{c}0.537 \\
(0.04)\end{array}$ & $\begin{array}{c}0.200 \\
(0.03)\end{array}$ & $\begin{array}{c}0.283 \\
(0.02)\end{array}$ & 589 \\
\hline EARLY MARRIAGE HAS NO BENEFITS & $\begin{array}{c}0.235 \\
(0.03)\end{array}$ & $\begin{array}{c}0.578 \\
(0.04)\end{array}$ & $\begin{array}{c}0.898 \\
(0.02)\end{array}$ & $\begin{array}{c}0.620 \\
(0.02)\end{array}$ & 584 \\
\hline \multicolumn{6}{|l|}{ Experiences } \\
\hline CIRCUMCISED & $\begin{array}{c}0.941 \\
(0.02)\end{array}$ & $\begin{array}{c}0.900 \\
(0.04)\end{array}$ & $\begin{array}{r}0.855 \\
(0.04)\end{array}$ & $\begin{array}{c}0.891 \\
(0.02)\end{array}$ & 302 \\
\hline MARRIED BEFORE AGE EIGHTEEN & $\begin{array}{c}0.688 \\
(0.08)\end{array}$ & $\begin{array}{c}0.427 \\
(0.10)\end{array}$ & $\begin{array}{r}0.319 \\
(0.07)\end{array}$ & $\begin{array}{c}0.432 \\
(0.05)\end{array}$ & 134 \\
\hline \multicolumn{6}{|l|}{ Behavior/intentions } \\
\hline DAUGHTER CIRCUMCISED & $\begin{array}{c}0.542 \\
(0.05)\end{array}$ & $\begin{array}{c}0.569 \\
(0.05)\end{array}$ & $\begin{array}{c}0.520 \\
(0.05)\end{array}$ & $\begin{array}{c}0.542 \\
(0.03)\end{array}$ & 326 \\
\hline DAUGHTER MARRIED BEFORE AGE EIGHTEEN & $\begin{array}{c}0.749 \\
(0.09)\end{array}$ & $\begin{array}{c}0.604 \\
(0.10)\end{array}$ & $\begin{array}{c}0.384 \\
(0.10)\end{array}$ & $\begin{array}{c}0.551 \\
(0.06)\end{array}$ & $96^{1}$ \\
\hline PLAN TO CIRCUMCISE DAUGHTER IN FUTURE & $\begin{array}{c}0.843 \\
(0.04)\end{array}$ & $\begin{array}{c}0.479 \\
(0.06)\end{array}$ & $\begin{array}{r}0.551 \\
(0.06)\end{array}$ & $\begin{array}{c}0.596 \\
(0.03)\end{array}$ & 293 \\
\hline
\end{tabular}

Notes: Means weighted by inverse sampling probabilities. Standard errors are in parentheses.

1. Number of observations reflects the small number of respondents who both had married daughters and could estimate the age at which their daughters were married.

\section{Evaluation}

Before reporting treatment effects, it is important to establish that the treatment and control groups were indeed very similar in pretreatment covariates, because simple randomization will occasionally produce uneven results by chance. Table 2 presents the results of comparison-of-means tests for a series of demographic indicators. Among these only the difference in means for age is significant at the 10 percent level.

To investigate the presence of treatment effects in a regression framework, I employ both linear and nonlinear models. The linear model is represented as follows:

$$
\operatorname{Pr}\left(\mathrm{Y}_{\mathrm{i}}=1\right)=\gamma \text { treatment }_{\mathrm{i}}+\mathbf{x}_{\mathrm{i}}^{\prime} \boldsymbol{\beta}+\mathrm{u}_{\mathrm{i}}
$$

where treatment is a dummy variable for receiving the international audience prime, and $\mathbf{x}_{\mathbf{i}}$ is a vector of covariates. As a robustness check, I include two specificationsone in which I regress each of the ten outcome variable indicators on the international 
audience treatment alone $\left(\mathbf{x}_{\mathrm{i}}=0\right)$, and one in which I regress the outcome variables on the treatment and a series of controls. ${ }^{60} \mathrm{I}$ also run both specifications using a nonlinear model. The logistic model is represented as follows:

$$
\operatorname{Pr}\left(\mathrm{Y}_{\mathrm{i}}=1\right)=f\left(\gamma \text { treatment }_{\mathrm{i}}+\mathbf{x}_{\mathrm{i}}^{\prime} \boldsymbol{\beta}\right),
$$

where $f$ is the following logistic function:

$$
f(\mathrm{z})=1 /\left(1+\mathrm{e}^{-\mathrm{z}}\right)=\Lambda(\mathrm{z})
$$

Table 3 presents the results for each of the outcome variables. Models 1 and 2 are the linear ordinary least squares (OLS) analyses, Models 3 and 4 are the nonlinear (logit) analyses with robust standard errors, and Models 5 and 6 are also nonlinear analyses, but with standard errors that have been clustered and weighted to take account of the survey design. The table presents marginal effects coefficients for the nonlinear models (Models 3 to 6) to ensure comparability with the OLS coefficients.

TABLE 2. Comparison of covariate means by treatment (international audience)

\begin{tabular}{lccc}
\hline Variable & Treatment & Control & Difference in means \\
\hline \multirow{2}{*}{ FEMALE } & 0.50 & 0.50 & 0.00 \\
AGE & $(0.03)$ & $(0.03)$ & $(0.04)$ \\
& 35.75 & 33.36 & $2.39 *$ \\
LEVEL OF EDUCATION & $(0.89)$ & $(0.89)$ & $(1.26)$ \\
MARRIED & 1.36 & 1.31 & 0.05 \\
& $(0.10)$ & $(0.10)$ & $(0.14)$ \\
PASTORALIST & 0.68 & 0.63 & 0.04 \\
& $(0.03)$ & $(0.03)$ & $(0.04)$ \\
PROTESTANT & 0.51 & 0.45 & 0.06 \\
CATHOLIC & $(0.03)$ & $(0.03)$ & $(0.04)$ \\
& 0.33 & 0.37 & -0.04 \\
TRADITIONAL RELIGION & $(0.03)$ & $(0.03)$ & $(0.04)$ \\
RADIO OWNERSHIP & 0.36 & 0.32 & 0.04 \\
& $(0.03)$ & $(0.03)$ & $(0.04)$ \\
\end{tabular}

Note: $* p<.10$.

The results show a clear difference between the impact that receiving the treatment prime has on expressed attitudes and experiences, compared with the impact it has on expressed past behavior and intended future behavior. Among the behavior-related outcome variables, I find that receiving the treatment prime is negatively and significantly associated with the probability that the respondent plans to circumcise a daughter in the future, and with the probability that the respondent reports having a daughter 
TABLE 3. Impact of international audience treatment on respondents' attitudes, experiences, and behavior

\begin{tabular}{|c|c|c|c|c|c|c|}
\hline \multirow[b]{2}{*}{ Outcome variable } & \multicolumn{2}{|c|}{$O L S$} & \multicolumn{2}{|c|}{ Logit } & \multicolumn{2}{|c|}{ Logit } \\
\hline & $\begin{array}{c}\text { (1) } \\
\text { Treatment only }\end{array}$ & $\begin{array}{c}\text { (2) } \\
\text { Full model }\end{array}$ & $\begin{array}{c}\text { (3) } \\
\text { Treatment only }\end{array}$ & $\begin{array}{c}\text { (4) } \\
\text { Full model }\end{array}$ & $\begin{array}{c}\text { (5) } \\
\text { Treatment only }\end{array}$ & $\begin{array}{c}\text { (6) } \\
\text { Full model }\end{array}$ \\
\hline FEMALE CIRCUMCISION SHOULD STOP & $\begin{array}{l}0.016 \\
(0.04)\end{array}$ & $\begin{array}{c}0.016 \\
(0.04)\end{array}$ & $\begin{array}{l}0.016 \\
(0.04)\end{array}$ & $\begin{array}{l}0.026 \\
(0.05)\end{array}$ & $\begin{array}{l}0.006 \\
(0.03)\end{array}$ & $\begin{array}{c}0.022 \\
(0.04)\end{array}$ \\
\hline EARLY MARRIAGE SHOULD STOP & $\begin{array}{r}0.047 \\
(0.04)\end{array}$ & $\begin{array}{c}0.049 \\
(0.03)\end{array}$ & $\begin{array}{c}0.047 \\
(0.04)\end{array}$ & $\begin{array}{l}0.083 \\
(0.06)\end{array}$ & $\begin{array}{c}0.043 \\
(0.03)\end{array}$ & $\begin{array}{r}0.087 \\
(0.04)\end{array}$ \\
\hline FEMALE CIRCUMCISION HAS NO BENEFITS & $\begin{array}{c}-0.010 \\
(0.04)\end{array}$ & $\begin{array}{r}0.001 \\
(0.03)\end{array}$ & $\begin{array}{c}-0.010 \\
(0.04)\end{array}$ & $\begin{array}{c}0.004 \\
(0.04)\end{array}$ & $\begin{array}{r}-0.034 \\
(0.04)\end{array}$ & $\begin{array}{r}-0.001 \\
(0.04)\end{array}$ \\
\hline EARLY MARRIAGE HAS NO BENEFITS & $\begin{array}{c}-0.010 \\
(0.04)\end{array}$ & $\begin{array}{c}0.021 \\
(0.03)\end{array}$ & $\begin{array}{c}-0.010 \\
(0.04)\end{array}$ & $\begin{array}{l}0.025 \\
(0.05)\end{array}$ & $\begin{array}{r}-0.041 \\
(0.05)\end{array}$ & $\begin{array}{c}0.001 \\
(0.06)\end{array}$ \\
\hline PREFER SON MARRY CIRCUMCISED WOMAN & $\begin{array}{c}0.008 \\
(0.04)\end{array}$ & $\begin{array}{c}-0.012 \\
(0.04)\end{array}$ & $\begin{array}{c}0.008 \\
(0.04)\end{array}$ & $\begin{array}{c}-0.015 \\
(0.05)\end{array}$ & $\begin{array}{c}0.032 \\
(0.03)\end{array}$ & $\begin{array}{c}0.005 \\
(0.06)\end{array}$ \\
\hline CIRCUMCISED & $\begin{array}{c}0.022 \\
(0.03)\end{array}$ & $\begin{array}{c}-0.010 \\
(0.03)\end{array}$ & $\begin{array}{c}0.022 \\
(0.03)\end{array}$ & $\begin{array}{c}-0.005 \\
(0.01)\end{array}$ & $\begin{array}{c}0.028 \\
(0.04)\end{array}$ & $\begin{array}{c}-0.006 \\
(0.02)\end{array}$ \\
\hline MARRIED BEFORE AGE EIGHTEEN & $\begin{array}{r}0.009 \\
(0.09)\end{array}$ & $\begin{array}{c}0.024 \\
(0.09)\end{array}$ & $\begin{array}{r}0.009 \\
(0.09)\end{array}$ & $\begin{array}{r}0.027 \\
(0.10)\end{array}$ & $\begin{array}{c}-0.081 \\
(0.13)\end{array}$ & $\begin{array}{c}-0.086 \\
(0.15)\end{array}$ \\
\hline DAUGHTER CIRCUMCISED & $\begin{array}{r}-0.010 \\
(0.06)\end{array}$ & $\begin{array}{c}-0.060 \\
(0.05)\end{array}$ & $\begin{array}{c}-0.018 \\
(0.06)\end{array}$ & $\begin{array}{c}-0.117 \\
(0.08)\end{array}$ & $\begin{array}{r}-0.013 \\
(0.03)\end{array}$ & $\begin{array}{l}-0.127 * * * \\
(0.05)\end{array}$ \\
\hline DAUGHTER MARRIED BEFORE AGE EIGHTEEN & $\begin{array}{l}-0.216^{* *} \\
(0.10)\end{array}$ & $\begin{array}{l}-0.235^{* *} \\
(0.11)\end{array}$ & $\begin{array}{l}-0.216^{* * *} \\
(0.10)\end{array}$ & $\begin{array}{l}-0.285^{* * *} \\
(0.12)\end{array}$ & $\begin{array}{l}-0.304 * * * \\
(0.08)\end{array}$ & $\begin{array}{l}-0.355^{* * * *} \\
(0.12)\end{array}$ \\
\hline PLAN TO CIRCUMCISE DAUGHTER IN FUTURE & $\begin{array}{l}-0.116^{* *} \\
(0.06)\end{array}$ & $\begin{array}{l}-0.126^{* *} \\
(0.05)\end{array}$ & $\begin{array}{l}-0.116^{* *} \\
(0.06)\end{array}$ & $\begin{array}{l}-0.154 * * \\
(0.07)\end{array}$ & $\begin{array}{l}-0.145^{* *} \\
(0.07)\end{array}$ & $\begin{array}{c}-0.193 * \\
(0.10)\end{array}$ \\
\hline
\end{tabular}

Notes: Each cell is the product of a separate regression. For Models 1 to 4 , robust standard errors are in parentheses. For Models 5 and 6 , standard errors, in parentheses, are clustered by sampling sublocation and weighted by probability of selection. Models 3 to 6 show marginal effects coefficients. Treatment only models show the coefficient on the international audience treatment variable in a regression of the outcome variable on treatment. Full models show the treatment coefficient in a regression of the outcome variable on treatment and other covariates with hypothesized relationships to the outcome variable. These covariates are age, sex, religion, frequency of exposure to other ethnic groups, beliefs about elders' and chiefs' attitudes, and study area fixed effects. OLS $=$ ordinary least squares. $* p<.10 ; * * p<.05 ; * * p<.01$. 
who was subjected to early marriage. ${ }^{61}$ These results are robust across all six models, and the coefficients carry magnitudes that suggest the treatment effect is substantively meaningful. Receiving the treatment decreases the probability that a respondent will report plans to circumcise a daughter in the future by between eleven and nineteen percentage points, and decreases the probability that a respondent will report having a daughter who was subjected to early marriage by between twenty-one and thirty-five percentage points. ${ }^{62}$ In addition, I find that receiving the treatment prime is negatively associated with the probability that the respondent reports having a daughter who was subjected to female circumcision, but this finding is significant in Model 6 only.

Although people in all three case study communities were more likely to report international-norm-compliant past behavior and intended future behavior if they happened to be in the treatment group, the extent of this tendency varied. Figures 2 and 3 show the treatment effect on respondents' reports that they plan to circumcise a daughter in the future and that their most recently married daughter was married underage, disaggregated by study area. The graphs show that respondents in Oldonyiro are substantially less likely to misrepresent themselves than respondents in Mukogodo or Mau. This finding fits well with expectations, because people who have a low level of awareness about an international norm ought to be less likely to perceive any advantage to deceiving international actors. Because Oldonyiro respondents in both the treatment and control groups were more likely than respondents from Mukogodo or Mau to report that they had a daughter who was married underage or that they intended to circumcise a daughter in the future, the lower observed treatment effect in Oldonyiro is highly unlikely to be the product of greater compliance with the international norm.

Overall, then, when the outcome variables of interest relate to past behavior and intended future behavior, treatment effects are consistently large for the entire sample and vary across the study communities in predicable ways. However, as Table 3 shows, there appears to be no meaningful treatment effect for any of the outcome variables related to attitudes and experiences. ${ }^{63}$ Among the five indicators

61. With respect to the intention to circumcise, one could argue that this is not necessarily misrepresentation, because the action has not happened yet. It is possible that simply referencing an international audience in the context of the survey causes respondents to genuinely reevaluate their future plans. However, the priming statements do not specify what international actors believe, which means the prime is only meaningful if the respondent already has information about international audience preferences before participating in the survey. In that case, simply being reminded of the existence of an international audience is unlikely to cause a respondent to change their true plans on the spur of the moment-if that change were going to happen, it would almost certainly have occurred when the respondent first learned about the international audience's preferences, before the treatment intervention.

62. The larger treatment effect for the early marriage variable may be a product of the fact that only parents who were actually able to estimate the age of a daughter at her marriage were included in the sample. Among Maasai and Samburu, ages are often unknown, and are more likely to be known among those in higher education brackets. More educated individuals are also more likely to be aware of international norms against FGM and early marriage, and thus to misrepresent themselves in response to the international audience treatment.

63. Beyond the content of the response, there were also no significant differences between the treatment and control groups in the refusal rate for individual questions. 
for attitudes toward female circumcision and early marriage and the two indicators for respondents' own experiences, the treatment coefficients are substantively small and none are statistically significant. In addition, while receiving the treatment has a consistently positive association with the probability that the respondent reports thinking female circumcision should stop and thinking early marriage should stop, the signs of the treatment coefficients for the remaining attitude and experience variables are not consistent across models.

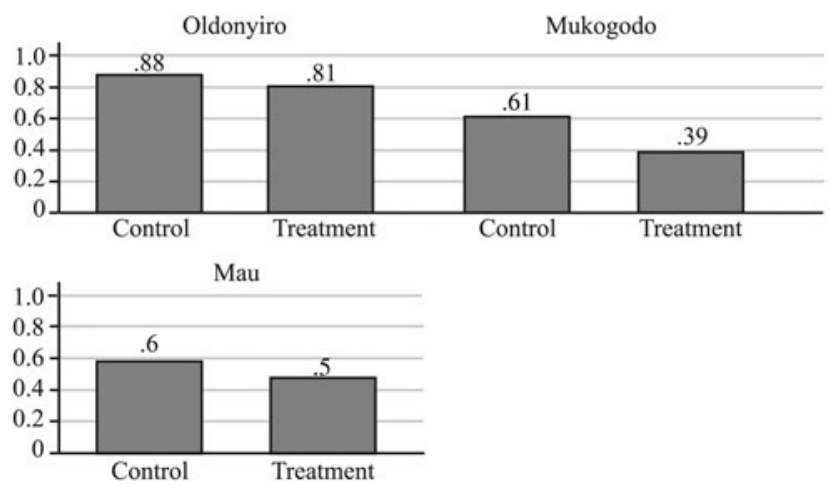

FIGURE 2. Plan to circumcise daughter in the future: Treatment effect by study area

Thus, there is a clear divergence between the treatment's impact on behaviorrelated variables and its impact on attitude- and experience-related variables. What might explain this? The social expectation of compliance is a unique and important feature of norms. The local norms supporting female circumcision and early marriage can have a strong influence even on those individuals who would like to defect from them. That is, agreeing with the international norm is not the same thing as actually complying with it. Indeed, survey respondents were consistently less supportive of female circumcision and early marriage when expressing their opinions than when expressing their past behavior and intended future behavior (see Table 1). Many of the people who state opposition to FGM may genuinely mean it, and yet they still plan to circumcise their daughters in the future. Similarly, parents-who have decision-making power over their daughters - may regret having subjected them to female circumcision or early marriage in the past. Especially since activism against FGM and early marriage is a relatively recent phenomenon, some of these parents may have adopted the international norm in the period after their daughters' circumcisions or early marriages.

These findings are largely in line with the psychology literature on self-presentation and deception, which argues that while straightforward material concerns may motivate some image management, many individuals primarily seek psychological rewards such as appearing consistent, modern, good, etc. These motivations are 

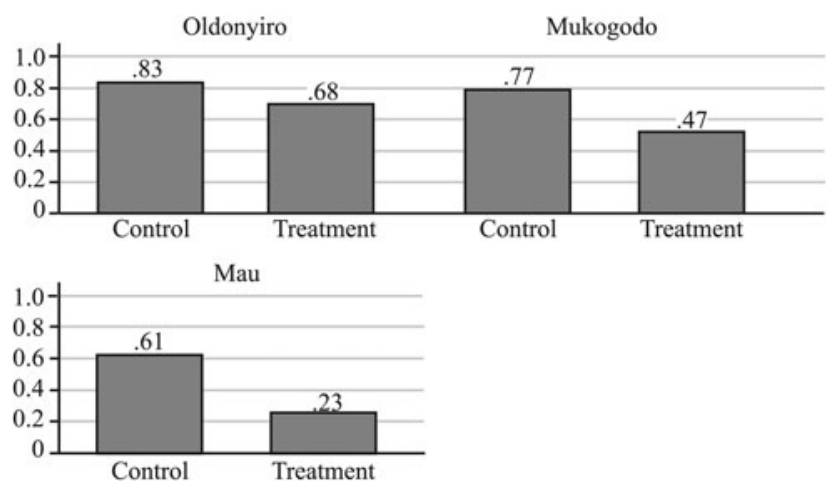

FIGURE 3. Daughter married before age eighteen: Treatment effect by study area

likely to be magnified when the audience is perceived as having high status. The findings are also consistent with constructivist IR theory on the power of norms to create desirable personas. Within this framework, respondents who have been truly fully compliant with the international norm have no reason to misrepresent their attitudes and behavior in the presence of an international audience. Similarly, those who are truly fully compliant with the local norm — still a majority of the population-may have little interest in misrepresenting their attitudes and behavior. In the face of transnational activism, continued true believers in the local norm are least likely to view the international audience as having high status, and thus to seek a good reputation in the eyes of that audience. The individuals with inconsistent attitudes and behavior, on the other hand-those who want to defect from the local norm, but are in the present or were in the past not quite confident enough to do so-have the incentive to impress an international audience but not the past behavior or intended future behavior to support it. I argue that these ambivalent individuals are most likely to misrepresent their behavior and intentions, so that they appear consistent with the international norm and with their own attitudes. ${ }^{64}$

An alternative explanation for the observed treatment effect, however, is that respondents misrepresent themselves to an international audience not because they hold that audience in high regard, but rather because they do not think it is possible to influence the way the international audience thinks about FGM or early marriage (whereas this might be possible if the audience were local), and so the most expedient strategy is to tell the international audience what it wants to hear and hope that leads

64. Under these conditions, one would not expect respondents to misrepresent their own experiences with female circumcision and marriage, since as previously discussed, girls have little control over either event. Because their parents ultimately held the decision-making power, female respondents who reported being circumcised or married before they turned eighteen would not necessarily see any inconsistency in admitting this while simultaneously voicing opposition to the two practices. 
the international audience to back off. Yet if this were the case, one would also expect to observe a treatment affect with respect to attitude-related survey questions.

Another alternative explanation is that respondents are in fact honestly representing their behavior and intentions to the international audience, and misrepresenting their behavior and intentions to the local audience. That is, some respondents are actually complying with the international norms, but report that they are complying with the local norms. But while this alternative story is possible, it is not consistent with the qualitative evidence. Moreover, there is no obvious reason for respondents to misrepresent themselves in this way, since the local audience depicted in the control priming statements includes local NGOs that are also officially opposed to FGM and early marriage (which most respondents would know since the communities are small and local NGOs tend to play a highly visible role in those communities). Thus, both the treatment and control groups are "exposed" to an audience that publicly opposes these practices - the critical difference between the two audiences is that the international audience has the ability to provide psychological benefits because it is a high-status group. ${ }^{65}$ In addition, even the treatment group was exposed to the local audience, if in a more limited way-as already mentioned, local NGOs served as the public face of the survey for all respondents, not just those in the control group. So if respondents were inclined to misrepresent themselves to a local audience, this would affect both the treatment and control groups, and thus could not account for the observed treatment effect. This is not, however, a claim that the control group point estimates are therefore necessarily "true"-as with any survey, the possibility of some kind of reporting bias remains, but any such bias ought to affect the treatment and control groups equally.

It is important to note that some kind of material motive might also be at work in these communities in addition to the psychological motive. However, the survey experiment was not designed to pick up material incentives for misrepresentation. The international audience prime presents that audience as remote- the international actors referenced in the priming statement are not described as being physically present in the communityand thus respondents could reasonably conclude that they were unlikely to receive any direct personal material benefits based on their answers. ${ }^{66}$ Perhaps a more likely source of material reward would be the local NGOs referenced in the local audience priming statement (though, as I mentioned earlier, most local NGOs are funded by international actors, and thus international actors would be the original source of any material rewards

\footnotetext{
65. One could perhaps imagine a scenario in which respondents misrepresent themselves to a lower-status group such as local NGOs precisely because those local NGOs are not viewed as important enough to require thoughtful, honest responses, but this reading of the evidence is inconsistent with the social psychology literature on self-presentation which suggests that misrepresentation is most likely to occur when one confronts a powerful or otherwise high-status audience.

66. However, this is in no way to suggest that international actors cannot be a source of material reward in the real world. Indeed, the qualitative interviews demonstrate clearly that they can be, particularly when foreign NGOs and foreign NGO workers visit rural communities as part of their activism. The only claim being made here is that it would be implausible for respondents in the treatment group to think that they might receive any material rewards from the international audience as a direct result of participating in the survey.
} 
disbursed by local NGOs). It is possible that some control group respondents perceived this and chose accordingly to represent their behavior and intentions as conforming to international norms. But if that is indeed the case, then the observed treatment effect is actually an underestimation of the true treatment effect.

\section{Qualitative Evidence}

Qualitative interviews can help to more fully draw out the mechanisms underlying individuals' misrepresentation of their behavior. Over the course of 2008, I conducted approximately 130 semi-structured in-depth interviews with NGO and CBO workers, local politicians, teachers, nurses and public health workers, government employees, church leaders, and traditional circumcisers and birth attendants in the three case study areas. All interviews consisted of open-ended questions, most of which were drawn from a protocol designed in advance of the interviews, but some of which were constructed on the spot to probe interviewees' responses. The vast majority of interviews were conducted in English, which is one of Kenya's two national languages and is widely spoken among those who have attended secondary school. On the rare occasions when an interviewee did not speak English, the interview was conducted in Maa with the aid of an interpreter. Many interviewees were selected through word of mouth, although I did speak with at least one person (usually the chairperson or director) from every active $\mathrm{NGO}$ or $\mathrm{CBO}$ in the three communities. The vast majority of qualitative interviews were conducted before the survey, and helped to inform the survey design.

The decision to conduct the survey among members of the general population while conducting the qualitative interviews among a narrower group of stakeholders was deliberate. The general population survey provides a representative picture of the three communities as a whole. The qualitative interviews provide an opportunity to dig deeper into the causal processes underlying individuals' misrepresentation of their behavior, but had these interviews been conducted among the general population, it likely would have been uncomfortable for people to discuss their personal experiences of FGM and early marriage with an outsider. Moreover, it is also likely that many interviewees would have been unwilling to admit that they personally misrepresented themselves to international actors. By targeting significant community players for qualitative interviews, it was possible to avoid asking about personal experiences entirely, and instead to ask interviewees to provide their insights into the larger trends in their communities. Each of the qualitative interviewees was chosen because they were sufficiently involved with the practices of FGM and early marriage, and the campaign against them, that they were able to speak, in a thoughtful manner, to the broader causal processes underlying individuals' misrepresentation of their behavior.

The results of these interviews produced several important findings: (1) misrepresentation is indeed taking place in the three communities; (2) reputational concerns motivate misrepresentation, particularly because foreigners are viewed as having high status; (3) material concerns also motivate misrepresentation; and (4) there are differences in the extent of misrepresentation across the three communities. 
First, interviewees pointed to the commonness of misrepresentation-many community members were inclined to impress, please, or simply humor international activists who come to their area, but these efforts did not necessarily signal a change in underlying behavior. According to one teacher, "With the campaign, even those who have undergone the cut [female circumcision], they will say 'I have not undergone the rite [of passage]."'67 If somebody in the community encounters a foreign activist, "They'll just hear [what the activist has to say] but they'll not take heed."68

Misrepresentation is made easier by the fact that foreign activists often come into the area for only brief visits, so there is no way for them to ascertain whether the people they meet are representing themselves honestly. ${ }^{69}$ This conforms to the expectation, derived from the social psychology literature, that misrepresentation will increase with the probability of being believed. According to several interviewees, community members will listen to outsiders, but as soon as these people leave, they will go back to their culture. ${ }^{70}$ In Oldonyiro, there are no locally based NGOs, so when the rare outside NGO comes in, according to the local government children's officer, people have an attitude of “'OK, we'll sit, we'll listen,' but when it comes to practicing [female circumcision], they'll still do it."71

Second, reputational motives featured heavily in the explanations for misrepresentation. Again conforming to expectations proposed in the literature on image management, many interviewees emphasized the high status that international actors wielded, especially among Maasai and Samburu populations. As one pastor put it, "They like white people like you. Since the beginning, they like hearing from the white [people]. They view them like friends." 72 Indeed, interviewees attributed a host of positive attributes to foreigners. Some focused on their perceived intelligence and knowledge, while others noted such qualities as altruism and honesty. ${ }^{73}$ One CBO board member said community members "just think that these people want to help them." 74 A public health officer said of local residents that "once they see a mzungu [Westerner], they normally view a mzungu like a person who knows everything. They normally say a mzungu is trustworthy. A mzungu does not cheat."75 One local government official said that "when a mzungu comes, first they will admire him or her, because wazungu [Westerners, plural] are rare. They are positive about the wazungu."76

67. Author's interview with head teacher ASM, September 2008, Mau, Kenya.

68. Author's interview with education officer MS, September 2008, Mau, Kenya.

69. Author's interview with head teacher AR, July 2008, Mukogodo, Kenya.

70. Author's interviews with gender and social development officer AG, July 2008, Oldonyiro, Kenya; public health workers I and Y, July 2008, Oldonyiro, Kenya; and former church women's development coordinator LL, October 2008, Oldonyiro, Kenya.

71. Author's interview with children's officer SJ, July 2008, Oldonyiro, Kenya.

72. Author's interview with pastor PN, September 2008, Mau, Kenya.

73. Author's interview with head teacher MK, July 2008, Mukogodo, Kenya.

74. Author's interview with CBO board member MK, July 2008, Mukogodo, Kenya.

75. Author's interview with public health worker FM, September 2008, Mau, Kenya.

76. Author's interview with district officer SM, September 2008, Mau, Kenya. 
Many perceived attributes of foreigners ultimately reflected unequal power relations, especially in terms of wealth, modernity, and worldliness. Community members "believe wazungu are always right. They believe a mzungu is advanced."77 "They always say, 'A mzungu is correct. They've got all the facts." 78 Some people also "think that [foreigners] have gone so many places."79 One pastor placed these beliefs in historical perspective: "People know that wazungu brought education and Christianity [to Kenya], so now they think wazungu will bring change and modernization. People desire change because they see that other groups and people have better and more comfortable lives." 80 A traditional birth attendant went so far as to say that Maasai do not think highly of themselves, so they want to emulate outsiders who are better respected or, at least by some measures, more successful. ${ }^{81}$

Of course, just because international actors enjoy a high-status reputation does not mean that local residents can easily change their actual behavior to conform to international norms. People might be impressed by outsiders, but they are unlikely to wholly reject female circumcision or early marriage, "even if you take ... a mzungu there." 82 According to one CBO director, "A mzungu [can't] influence our community, even though [community members] think the wazungu are superior. The wazungu are more modern, and they want to change the world fast, but our community thinks we should be changing gradually. They'll listen, but most Africans don't share very much [with] wazungu." 83 In the face of significant local pressure to continue to conform to local norms, it makes sense that some people, when they encounter international actors, would choose to hide the fact that they are still practicing FGM and early marriage. The cross-pressures from international and local actors make misrepresentation an attractive option. If people hide their behavior, "it's because they want to belong to both sides. They want to look civilized, and at the same time they want to be looked upon by their kinsmen as ones who have maintained their culture." 84

Third, while the survey experiment was not designed to capture material incentives for misrepresentation, quite a few of the qualitative interviewees stated that in addition to reputational concerns associated with status, material interests also motivated many community members to misrepresent their attitudes and behavior to international activists. These material incentives are significant because many Maasai and Samburu live on subsistence incomes and are dependent on some form of outside assistance. Many seem to believe that expressing agreement with activists' priorities is a good idea since activists bring resources into the community.

77. Author's interview with community development official MO, July 2008, Mukogodo, Kenya.

78. Author's interview with public health worker DL, October 2008, Oldonyiro, Kenya.

79. Author's interview with CBO worker AK, September 2008, Mau, Kenya.

80. Author's interview with pastor MS, October 2008, Mau, Kenya.

81. Author's interview with traditional birth attendant MN, August 2008, Mau, Kenya.

82. Author's interview with head teacher MK, July 2008, Mukogodo, Kenya.

83. Author's interview with CBO director AM, July 2008, Mukogodo, Kenya.

84. Author's interview with deputy head teacher VML, September 2008, Mau, Kenya. 
According to one chief, "Most of the NGOs were started by people from outside Kenya. They are always welcome, because some have benefited a lot from [these] people." 85 Another chief reported that "they respect the NGOs because most of the NGOs fund the community."86 Some interviewees discussed this relationship between activists and locals quite explicitly. According to one teacher, "A person coming from far [away] would only have an impact if he brings some rewards," 87 such as sponsoring girls to go to secondary school, starting a clean water project, or building a school or hospital. ${ }^{88}$ Another reported that "a mzungu is different from any other African. The rural [people] will be very keen to listen to you. They think that you will be bringing maybe some financial support. They will always see that maybe they will get something from you. They expect some advantage, some support from that mzungu." 89 A public health officer claimed that if you are a foreigner, "You are likely to be listened to so much. You will be given so much attention, because [locals] think that you always come with goodies." 90

Local NGOs are not immune to these kinds of expectations, however. Whether conducted by international, national, or local organizations, events and trainings against FGM and early marriage usually provide food or some kind of payment, and this incentive alone can bring in hundreds of people. In some cases, attendees will be expected to verbally express their opposition to the practices within the context of the event. For example, many organizations run so-called Alternative Rites of Passage, which are supposed to recreate female circumcision's symbolic transition to adulthood. Girls go through as much as a week of training related to what it means to be a woman in Maasai or Samburu society, generally culminating in a ceremony in which the girls and their families pledge not to engage in circumcision. If parents let their daughters participate in the Alternative Rite of Passage, the whole family is likely to receive a free lunch at the ceremony, or possibly a goat. Later, though, many of these same girls will undergo a low-profile circumcision. ${ }^{91}$

Even basic seminars and workshops can draw crowds. People come to these seminars regardless of the topic because they are hoping for a free lunch, yet by their presence they are at least tacitly signaling their opposition to these practices. 92 "People are fond of meetings but they aren't really persuaded by them."93 One teacher reported that "when people hear of NGOs, they attend that meeting expecting to be given [something]. People think that NGOs are there to give out."94 According to a

85. Author's interview with Chief SK, September 2008, Mau, Kenya.

86. Author's interview with Assistant Chief FL, October 2008, Oldonyiro, Kenya.

87. Author's interview with head teacher ASM, September 2008, Mau, Kenya.

88. Author's interviews with CBO chairwoman HK, September 2008, Mau, Kenya; and district officer, July 2008, Oldonyiro, Kenya.

89. Author's interview with head teacher SL, October 2008, Oldonyiro, Kenya.

90. Author's interview with public health officer SS, September 2008, Mau, Kenya.

91. Author's interview with NGO worker JK, June 2008, Mukogodo, Kenya.

92. Author's interview with head teacher AR, July 2008, Mukogodo, Kenya.

93. Author's interview with Father J, October 2008, Mukogodo, Kenya.

94. Author's interview with head teacher SKK, September 2008, Mau, Kenya. 
priest, "You have to pay [people] when they come to listen. They call it a sitting allowance. If you pay them, at the next meeting you will have so many people, not because of the message, but because of the payment they are getting." 95 One NGO worker recalled that when her organization first started holding meetings, they only provided sodas and other small items. Many people came to the first meeting, thinking they would receive something more substantial. But after discovering that they were only getting soda, they did not come to any of the future meetings. ${ }^{96}$

Although both international and local activists may encounter misrepresentation from the communities they are attempting to persuade, it is also sometimes the case that local NGO and CBO workers themselves misrepresent their true beliefs and behavior for material benefit, because they are essentially being paid to speak out against FGM and early marriage. According to one CBO director:

After some time we felt that a lot of [local] organizations are simply just using double-speak. They talk so passionately against these things when it comes to seeing white people like you, donors, other kinds of [foreigners], but when it comes to the reality on the ground, they don't have the confidence to say that exactly. Because of peer pressure, and because of the rite of passage, which is part of the community as a whole, the culture, it is very difficult to just [change]. Right now, those [local] people spearheading this [campaign], all of their daughters, and also their sisters, are undergoing the operation without a voice. ${ }^{97}$

Another local activist reported that many grassroots NGO workers marry circumcised girls, so they have lost credibility in the community. The local NGOs are addressing FGM because they think they will get more money from donors, so they tell foreigners what they think they want to hear. ${ }^{98}$ According to one elder, "We see [local activists] as business people. They have business minds, so they come and try to seduce us [away from FGM], because when a person stands against FGM they will get funds from outside, from groups or NGOs, maybe in the US." 99

Fourth, consistent with the survey results, regional differences appeared to play some role in explaining how community members interacted with international audiences. In particular, the relative infrequency of interactions with foreigners in Oldonyiro lent an air of novelty to these exchanges that was not quite matched in the other communities. Because of this, interviewees in Oldonyiro were less likely to report that community members' interactions with foreigners were purely material or to be jaded about the possible benefits international actors could provide. More generally, interviewees in Oldonyiro were less likely than interviewees in

95. Author's interview with Father AG, October 2008, Oldonyiro, Kenya.

96. Author's interview with NGO worker RK, September 2008, Mau, Kenya.

97. Author's interview with CBO director JK, April 2008, Mukogodo, Kenya.

98. Author's interview with children's home manager HG, June 2008, Mukogodo, Kenya.

99. Author's interview with age set leader KK, October 2008, Mau, Kenya. 
Mukogodo or Mau to have anything at all to say about locals' responses to international pressure, because they could not speak about events that had not happened.

\section{Conclusion}

One can conclude from the combined analyses that individuals, like states, sometimes face incentives to conceal their true attitudes and behavior in response to transnational activism. In a conflict between international and local norms, identities and cultural ties are tested. With globalization, individuals and communities that may once have been isolated are now embedded in larger networks, and must weigh competing demands on their loyalties. The local targets of transnational activism are being pulled in opposing directions - toward "tradition" and local expectations on the one hand, and toward "modernization" and international expectations on the other.

In response to this conflict, some people will represent themselves honestly at the risk of alienating or angering one side or the other, and some will try to please everyone through ultimately dishonest means. Both the survey experiment analysis and qualitative interviews show a clear tendency toward misrepresentation when individuals believe they have something to gain from doing so. The quantitative data support the idea that one can derive psychological benefits from misrepresenting oneself to international actors, and the qualitative data support a material benefits story in addition to the psychological one. These dual psychological and material impulses parallel both the moral bent of constructivism and the instrumentalist bent of rational actor models in IR theory.

On a more general note, the experimental design provides some leverage on questions about the broader reliability of survey responses with respect to sensitive topics - the percentage difference between the treatment and control groups in their responses to various questions yields a sense of the magnitude of the misrepresentation problem.

That some people choose to misrepresent their behavior with respect to FGM and early marriage does not automatically signify the failure of activist efforts to produce real norm change, however. First, the fact that many people want to be perceived as compliant with the international norm could be regarded as a first step in the process of norm change. Indeed, much of the transnational advocacy literature hinges on the idea that "cheap talk" in favor of international norms can ultimately be used to leverage real behavior changes. ${ }^{100}$ Moreover, although some rhetorical norm adopters may be motivated by purely material considerations, it seems clear from both the qualitative and quantitative evidence that others genuinely subscribe to the logic of the international norm or at least seek the approbation of international actors; it is only that they have not been bold enough to take the step from attitude change to behavior change.

Second, the more that people are willing to profess compliance with the international norm, the more it sends a signal to others in the community that the local 
norm is softening. Fellow community members will likely guess that not all of these statements are genuine, but if the local norm were truly unassailable, then only the most materially minded would have an incentive to misrepresent their behavior. As a new generation grows up, it may be less likely to perceive anything disingenuous in these statements, and simply take them at face value. Although no single statement of international norm compliance is above reproach, the sum total of these statements sends a message that some people are abandoning FGM or early marriage, and this may lower the barriers for others to defect in reality.

These findings have broader ramifications for how one might think about other transnational campaigns. It is relevant not just for evaluating campaigns against FGM and early marriage in other contexts, but also for investigating the clash between international and local norms around a range of other issues. Potential applications include the campaign against poaching of endangered and threatened species, and the campaigns to promote condom use, vaccinations, and other positive behaviors in the realm of public health. Moreover, it has applications to a host of other international norms related to gender-based violence and women's rights, including campaigns against domestic violence, sexual violence, honor killings, force feeding, and bride burning. Wherever local norms lag behind international expectations, it is worth considering how communities will respond to transnational campaigning.

There is real value in understanding such local processes. By focusing on the local level, the mechanisms of norm transmission are easier to observe, allowing one to see inside the black box of international norm promotion. Any change on the world scale is ultimately the aggregation of change on the part of individuals and communitiesby understanding their motivations and interests, one starts to grasp the varied paths by which international norms exert their influence.

\section{Supplementary material}

Replication data and online appendix available at http://dx.doi.org/10.1017/ S0020818314000022.

\section{References}

Buss, Arnold H., and Stephen R. Briggs. 1984. Drama and the Self in Social Interaction. Journal of Personality and Social Psychology 47 (6):1310-24.

Cloward, Karisa. Forthcoming. Elites, Exit Options, and Social Barriers to Norm Change: The Complex Case of Female Genital Mutilation. Studies in Comparative International Development.

Cronk, Lee. 2004. From Mukogodo to Maasai: Ethnicity and Cultural Change in Kenya. Boulder, CO: Westview Press.

DePaulo, Bella M., Deborah A. Kashy, Susan E. Kirkendol, Melissa M. Wyer, and Jennifer A. Epstein. 1996. Lying in Everyday Life. Journal of Personality and Social Psychology 70 (5):979-95. 
Edwards, Michael, and David Hulme. 1995. NGO Performance and Accountability: Introduction and Overview. In Non-Governmental Organisations-Performance and Accountability: Beyond the Magic Bullet, edited by Michael Edwards and David Hulme, 3-16. London: Earthscan.

Finnemore, Martha. 1993. International Organizations as Teachers of Norms: The United Nations Educational, Scientific, and Cultural Organization and Science Policy. International Organization 47 (4):565-97.

Finnemore, Martha, and Kathryn Sikkink. 1998. International Norm Dynamics and Political Change. International Organization 52 (4):887-917.

Goffman, Erving. 1973 [1959]. The Presentation of Self in Everyday Life. Woodstock, NY: Overlook Press.

Goodman, Ryan, and Derek Jinks. 2013. Social Mechanisms to Promote International Human Rights: Complementary or Contradictory? In The Persistent Power of Human Rights: From Commitment to Compliance, edited by Thomas Risse, Stephen C. Ropp, and Kathryn Sikkink, 103-21. New York: Cambridge University Press.

Hafner-Burton, Emilie M., and Kiyoteru Tsutsui. 2005. Human Rights in a Globalizing World: The Paradox of Empty Promises. American Journal of Sociology 110 (5):1373-411.

Hathaway, Oona A. 2002. Do Human Rights Treaties Make a Difference? Yale Law Journal 111 (8): 1935-2042.

- 2003. The Cost of Commitment. Stanford Law Review 55 (5):1821-62.

2007. Why Do Countries Commit to Human Rights Treaties? Journal of Conflict Resolution 51 (4):588-621.

Hulme, David, and Michael Edwards. 1997. NGOs, States and Donors: An Overview. In NGOs, States and Donors: Too Close for Comfort? edited by David Hulme and Michael Edwards, 3-22. New York: St. Martin's Press/Save the Children.

Hyde, Susan D. 2011. The Pseudo-Democrat's Dilemma: Why Election Observation Became an International Norm. Ithaca, NY: Cornell University Press.

International Planned Parenthood Federation (IPPF). 2006. Ending Child Marriage: A Guide for Global Policy Action. London: IPPF.

Johnson, Janet Elise. 2009. Gender Violence in Russia: The Politics of Feminist Intervention. Bloomington: Indiana University Press.

Jones, Edward E. 1990. Interpersonal Perception. New York: Freeman.

Keck, Margaret E., and Kathryn Sikkink. 1998. Activists Beyond Borders: Advocacy Networks in International Politics. Ithaca, NY: Cornell University Press.

Kenya Central Bureau of Statistics (CBS). 1989. 1989 Population and Housing Census. Nairobi: Kenya CBS.

Kenya Central Bureau of Statistics (CBS), Ministry of Health (MOH), and ORC Macro. 2004. Kenya Demographic and Health Survey 2003. Calverton, MD: Kenya CBS, MOH, and ORC Macro.

Kenya National Bureau of Statistics (KNBS) and ICF Macro. 2010. Kenya Demographic and Health Survey 2008-09. Calverton, MD: KNBS and ICF Macro.

Kenya National Council for Population and Development (NCPD), Central Bureau of Statistics (CBS), and Macro International. 1999. Kenya Demographic and Health Survey 1998. Calverton, MD: Kenya NCPD, CBS, and Macro International.

Klotz, Audie. 1995. Norms in International Relations: The Struggle Against Apartheid. Ithaca, NY: Cornell University Press.

Leary, Mark R., and Robin M. Kowalski. 1990. Impression Management: A Literature Review and TwoComponent Model. Psychological Bulletin 107 (1):34-47.

Lutz, Ellen L., and Kathryn Sikkink. 2000. International Human Rights Law and Practice in Latin America. International Organization 54 (3):633-59.

Mackie, Gerry. 1996. Ending Footbinding and Infibulation: A Convention Account. American Sociological Review 61 (6):999-1017.

Merry, Sally Engle. 2006. Human Rights and Gender Violence: Translating International Law into Local Justice. Chicago: University of Chicago Press.

Nadelmann, Ethan A. 1990. Global Prohibition Regimes: The Evolution of Norms in International Society. International Organization 44 (4):479-526. 
Nowak, Andrzej, Jacek Szamrej, and Bibb Latané. 1990. From Private Attitude to Public Opinion: A Dynamic Theory of Social Impact. Psychological Review 97 (3):362-76.

Ottaway, Marina, and Thomas Carothers. 2000. Toward Civil Society Realism. In Funding Virtue: Civil Society Aid and Democracy Promotion, edited by Marina Ottaway and Thomas Carothers, 293-310. Washington, DC: Carnegie Endowment for International Peace.

Parry, Hugh J., and Helen M. Crossley. 1950. Validity of Responses to Survey Questions. Public Opinion Quarterly 14 (1):61-80.

Phillips, Derek L., and Kevin J. Clancy. 1972. Some Effects of "Social Desirability" in Survey Studies. American Journal of Sociology 77 (5):921-40.

Price, Richard. 1998. Reversing the Gun Sights: Transnational Civil Society Targets Land Mines. International Organization 52 (3):613-44.

Risse, Thomas, and Kathryn Sikkink. 1999. The Socialization of International Human Rights Norms into Domestic Practices: An Introduction. In The Power of Human Rights: International Norms and Domestic Change, edited by Thomas Risse, Stephen C. Ropp, and Kathryn Sikkink, 1-38. New York: Cambridge University Press.

Schlenker, Barry R., and Michael F. Weigold. 1989. Goals and the Self-Identification Process: Constructing Desired Identities. In Goal Concepts in Personality and Social Psychology, edited by Lawrence A. Pervin, 243-90. Hillsdale, NJ: Lawrence Erlbaum.

1992. Interpersonal Processes Involving Impression Regulation and Management. Annual Review of Psychology 43:133-68.

Simmons, Beth. 2010. Treaty Compliance and Violation. Annual Review of Political Science 13:273-96.

Smillie, Ian. 1995. Painting Canadian Roses Red. In Non-Governmental Organisations-Performance and Accountability: Beyond the Magic Bullet, edited by Michael Edwards and David Hulme, 157-66. London: Earthscan.

Sommer, Gabriele, and Rainer Vossen. 1993. Dialects, Sectiolects, or Simply Lects? The Maa Language in Time Perspective. In Being Maasai: Ethnicity and Identity in East Africa, edited by Thomas Spear and Richard Waller, 25-37. Athens: Ohio University Press.

Subotic, Jelena. 2009. Hijacked Justice: Dealing with the Past in the Balkans. Ithaca, NY: Cornell University Press.

Sundstrom, Lisa McIntosh. 2005. Foreign Assistance, International Norms, and NGO Development: Lessons from the Russian Campaign. International Organization 59 (2):419-49.

- 2006. Funding Civil Society: Foreign Assistance and NGO Development in Russia. Stanford, CA: Stanford University Press.

Tetlock, Philip E., and A.S.R. Manstead. 1985. Impression Management Versus Intrapsychic Explanations in Social Psychology: A Useful Dichotomy? Psychological Review 92 (1):59-77.

Türk Smith, Seyda, Kyle D. Smith, and Kristen J. Seymour. 1993. Social Desirability of Personality Items as a Predictor of Endorsement: A Cross-Cultural Analysis. Journal of Social Psychology 133 (1):43-52.

United Nations Children's Fund (UNICEF). 2009. Progress for Children: A Report Card on Child Protection. New York: UNICEF.

- 2013. Female Genital Mutilation/Cutting: A Statistical Overview and Exploration of the Dynamics of Change. New York: UNICEF.

United Nations Children's Fund (UNICEF) Innocenti Research Center. 2001. Early Marriage: Child Spouses. Innocenti Digest 7. Florence: UNICEF Innocenti Research Center.

2005. Changing a Harmful Social Convention: Female Genital Mutilation/Cutting. Innocenti Digest 12. Florence: UNICEF Innocenti Research Center.

Vreeland, James Raymond. 2008. Political Institutions and Human Rights: Why Dictatorships Enter into the United Nations Convention Against Torture. International Organization 62 (1):65-101.

Williams, John E., Robert C. Satterwhite, and José L. Saiz. 1998. The Importance of Psychological Traits: A Cross-Cultural Study. New York: Plenum Press.

World Health Organization (WHO). 2008. Fact Sheet No. 241: Female Genital Mutilation. Geneva: WHO Press. Available at <http://www.who.int/mediacentre/factsheets/fs241/en/>. Accessed 12 March 2009. 